\title{
Sickle Cell Nephropathy
}

National Cancer Institute

\section{Source}

National Cancer Institute. Sickle Cell Nephropathy. NCI Thesaurus. Code C123203.

Nephropathy secondary to sickle cell disease, characterized by the presence of sickled erythrocytes in the renal medullary vessels, renal ischemia and microinfarctions, renal papillary necrosis, and renal tubular abnormalities. 